\title{
Physicochemical properties of double-stranded RNA used to discover a reo-like virus from blue crab Callinectes sapidus
}

\author{
Holly A. Bowers ${ }^{1}$, Gretchen A. Messick ${ }^{2}$, Ammar Hanif ${ }^{1}$, Rosemary Jagus ${ }^{1}$, \\ Lee Carrion ${ }^{3}$, Oded Zmora ${ }^{4}$, Eric J. Schott ${ }^{1, *}$
}

${ }^{1}$ Institute of Marine and Environmental Technology, University of Maryland Center for Environmental Science, Baltimore, Maryland 21202, USA

${ }^{2}$ Center for Coastal Environmental Health \& Biomolecular Research at Charleston USDOC/NOAA/NOS/NCCOS, Oxford, Maryland 21654, USA

${ }^{3}$ Coveside Crabs, Inc., Dundalk, Maryland 21222, USA

${ }^{4}$ Institute of Marine and Environmental Technology, University of Maryland Baltimore County, Baltimore, Maryland 21202, USA

\begin{abstract}
Mortality among blue crab Callinectes sapidus in soft shell production facilities is typically $25 \%$ or greater. The harvest, handling, and husbandry practices of soft shell crab production have the potential to spread or exacerbate infectious crab diseases. To investigate the possible role of viruses in soft shell crab mortalities, we took advantage of the physicochemical properties of doublestranded RNA (dsRNA) to isolate a putative virus genome. Further characterization confirmed the presence of a reo-like virus that possesses 12 dsRNA genome segments. The virus was present in $>50 \%$ of dead or dying soft shell crabs, but fewer than $5 \%$ of healthy hard crabs. Injection of the virus caused mortality and resulted in the appearance of viral RNA and virus inclusions in hemocytes. The genome of the virus was partially sequenced and the information used to develop a reverse transcription polymerase chain reaction (RT-PCR) assay that is able to detect the virus genome in as little as $7.5 \mathrm{pg}$ of total RNA. The molecular tools developed during this study will allow us to quantify prevalence of the blue crab reo-like virus in captive (soft shell facilities, aquaculture operations) and wild populations and facilitate understanding of the role this virus has in blue crab life history.
\end{abstract}

KEY WORDS: Reovirus · dsRNA $\cdot$ Disease $\cdot$ Callinectes sapidus $\cdot$ Aquaculture $\cdot$ Mortality

Resale or republication not permitted without written consent of the publisher

\section{INTRODUCTION}

The blue crab Callinectes sapidus is distributed across 2 hemispheres, from the north Atlantic coast of the United States to the coast of Uruguay in South America (Williams 1974). In the United States, the blue crab fishery has a dockside value of over US\$150 million (2008 data; NOAA-National Marine Fisheries); in Chesapeake Bay alone, the annual value of the harvest is valued at over $\$ 50$ million. The Chesapeake Bay blue crab population, once described as 'inexhaustible' (Smith 1891), has been in decline for more than a decade (Montane \& Lowery 2005, Maryland Depart- ment of Natural Resources 2008). Harvests in North Carolina and South Carolina have also been decreasing in recent years (NC Division of Marine Fisheries, SC Department of Natural Resources). The persistently low blue crab broodstock (mated females) in Chesapeake Bay stimulated the formation of a research consortium to study the life cycle of blue crab, with an assessment of hatchery-based broodstock enhancement (Zohar et al. 2008). This effort necessitated the production of over 100000 hatchery-reared juveniles $\mathrm{yr}^{-1}$ in the marine recirculating aquaculture facility at the Center of Marine Biotechnology (COMB; now named the Institute of Marine and Environmental 
Technology) in Baltimore, MD, USA (Zmora et al. 2005).

In 2008 the severe decline in Chesapeake Bay crab abundance triggered a declaration of fishery disaster by the United States Department of Commerce. To address over-fishing and broodstock depletion, unprecedented harvest restrictions were put in place by the states of Maryland and Virginia. Subsequently, the 2008-2009 estimate of age $1+$ blue crab abundance was $70 \%$ higher than the 2007-2008 estimate (Chesapeake Bay Stock Assessment Committee 2009). Typically there are also wide year-to-year swings in blue crab abundance that cannot be explained by fluctuations in fishing pressure. A recent paper by Hewitt et al. (2007) stressed that earlier estimates of natural mortality for blue crab were oversimplifications and therefore inaccurate. One recognized but poorly studied contributor to blue crab mortality is disease (Johnson 1983, Noga et al. 1998, Shields 2003). Although there are scores of diseases described in the blue crab (Shields \& Overstreet 2007), there is little understanding of their role in shaping blue crab populations.

In the face of decreasing or uncertain harvests, crabbers can increase the value of their catch by producing soft shell crabs. These are produced by segregating pre-molt animals from the catch, maintaining them in shallow enclosures ( 1 to $7 \mathrm{~d}$ ) until molting occurs, and collecting the soft crabs for fresh or frozen shipment to market. Blue crabs in soft shell production facilities typically suffer mortality rates of $25 \%$ or more (Chaves \& Eggleston 2003). This results in loss of time and effort to fishermen, and a loss of fishery resources. Soft shell crab mortality has been attributed to poor water quality (Lakshmi et al. 1984, Ary \& Poirrier 1989), though a study by Chaves \& Eggleston (2003) suggested a larger role for harvest/ transport stress. Overlying the stresses of harvesting and crowding is the physiological stress of molting. The combined stresses may render crabs more susceptible to infection by pathogenic organisms, especially viruses (Johnson 1977, Messick \& Kennedy 1990). Viruses are well known as a hindrance to shrimp aquaculture; however, there have been few reports on viruses in wild crustaceans. A notable exception is the growing literature on virus PaV1, found in the Caribbean spiny lobster Panulirus argus (e.g. Shields \& Behringer 2004, Butler et al. 2008).

Blue crabs may be infected by a spectrum of diseasecausing organisms, from macroscopically identifiable metazoans such as parasitic barnacles Loxothylacus sp. and trematodes Microphallus bassodactylus (Shields \& Overstreet 2007) to microscopically observable protists such as Microsporidia sp., Hematodinium sp., and Paramoeba sp. (Sprague \& Beckett 1966, Weidner 1970, Newman \& Johnson 1975). Crabs may also harbor infections by bacteria, especially Vibrio sp. (Welsh $\&$ Sizemore 1985). Most difficult to observe are viruses, which are visualized only in electron micrographs, though effects on infected cells may be observed by light microscopy. Blue crab viruses are reported to fall into at least 4 categories: baculo-like, picorna-like, rhabdo-like, and reo-like (Johnson \& Bodammer 1975, Jahromi 1977, Johnson 1983, 1984, Johnson \& Lightner 1988). The latter 3 virus types have genomes comprised of negative sense single-stranded RNA (ssRNA), positive sense ssRNA, and double-stranded RNA (dsRNA), respectively. To date there have been no published molecular characterizations of these viruses. A 1985 national soft shell blue crab conference recognized the need for rapid diagnostic tools to identify and monitor pathogens in the soft shell industry (Johnson 1986). Whether reflecting the limited resources of the artisanal soft shell crab industry or an under-appreciation of the potential role of disease, these tools are still not developed.

Advances in molecular techniques over the past 2 decades have made it feasible to develop rapid assays for specific crustacean viruses, based on virus genome information (e.g. white spot syndrome virus [WSSV] and Taura syndrome virus [TSV] in shrimp; Tsai et al. 2002, Navarro et al. 2009). Thus far, however, there have been no molecular tools developed to detect and identify viruses 'universally' in the manner that bacterial and eukaryotic genomes can be targeted by conserved or degenerate oligonucleotide primers (Lane 1991, Nejstgaard et al. 2003, Blankenship \& Yayanos 2005). RNA-based viruses are highly variable in sequence, and the only known gene displaying sequence conservation is the RNA-dependent RNA polymerase (RdRp; Culley et al. 2003). As part of the RNA virus replication cycle, RdRp generates antisense copies of RNA virus genomes. These antisense strands have the potential to anneal to genomic RNA molecules, producing dsRNA, which has physicochemical properties distinct from ssRNA and DNA (Fujimura et al. 2005). Most notably, dsRNA is less susceptible to nuclease degradation and can be highly enriched by column chromatography, based on its particular hydrophobicity.

We have investigated soft shell crab mortalities by looking directly for molecular evidence of virus infection. Because infections with RNA viruses, even those with single-stranded genomes, may produce dsRNA during replication (Ahlquist 2006, Weber et al. 2006), it may be possible to detect diverse virus genomes by enrichment of dsRNA from putatively infected animals (Summons \& Steaitss 1972, Morris-Krsinich \& Hull 1983). In an effort to develop and validate molecular tools for virus detection in Callinectes sapidus, we worked with a local soft shell facility that was experiencing high mortalities not attributable to other factors (e.g. water quality, handling). Using dsRNA enrichment methods, we investigated mortalities of soft shell crabs in a flow-through system. Herein, we describe using this approach to discover 
a reo-like virus that occurred in high prevalence in mortalities from diverse blue crab culture systems. In order to address major questions about the prevalence and transmission of this virus and to be able to detect sub-acute infections, we cloned part of the RNA genome of the virus and developed a reverse transcription polymerase chain reaction (RT-PCR) assay.

\section{MATERIALS AND METHODS}

Blue crab collections. Soft shell facilities: Moribund and healthy pre-molt or mid-molt crabs (125 to $150 \mathrm{~mm}$ carapace width) were collected from a commercial flowthrough soft shell production system near Baltimore. All crabs in the system were trapped in the vicinity of the Chesapeake Bay Bridge by the owner of the soft shell production facility. At the time of collection, water temperature was measured, and water samples were archived $\left(-20^{\circ} \mathrm{C}\right)$ for later water quality analysis. Crabs were dissected and selected tissues fixed in $4 \%$ formaldehyde $+1 \%$ glutaraldehyde for later histological assessments. Remaining animal tissues were archived at $-80^{\circ} \mathrm{C}$. Fixed tissues were stained with Meyer's hematoxylin and eosin (Luna 1968) for histological observations. Additional collections from soft shell production facilities were made at Tilghman Island, MD (flow through system), and near Tallahassee, FL (recirculating system). The Tilghman Island crabs were frozen upon collection and remained at $-20^{\circ} \mathrm{C}$ until analyses. Florida crabs were frozen $\left(-20^{\circ} \mathrm{C}\right)$, shipped overnight on ice, and subsequently stored at $-20^{\circ} \mathrm{C}$ until analysis. Freshly harvested crabs (Baltimore) were brought to the laboratory on wet ice, then stored at $-20^{\circ} \mathrm{C}$ until analysis.

Hatchery: The Institute of Marine and Environmental Technology (IMET, formerly the Center of Marine Biotechnology) biosecure recirculating hatchery has been described (Zmora et al. 2005). Crab production is based on wild-caught broodstock females, which produce broods of larvae in the hatchery. Occasional broodstock mortalities at COMB (2006-2007) were archived at $-20^{\circ} \mathrm{C}$ and at $-80^{\circ} \mathrm{C}$. Juvenile crabs were fed standard aquaculture diets (Zeigler Bros) and raised to 40 to $90 \mathrm{~mm}$ carapace width.

Molecular methods. Isolation of dsRNA: Total RNA was extracted from approximately $150 \mathrm{mg}$ of tissue (gill or muscle with hypodermis) using TRIzol ${ }^{\circledR}$ reagent (Invitrogen). Tissue was disrupted with 425 to $600 \mu \mathrm{m}$ acid-washed glass beads (Sigma Chemical) using a bead beater (Savant FastPrep ${ }^{\mathrm{TM}}$; Bio101) or TissueLyser (Qiagen). In preliminary studies, dsRNA was enriched using differential precipitation with $2 \mathrm{M} \mathrm{LiCl}$ (Diaz-Ruiz \& Kaper 1978). For subsequent studies the method for isolating dsRNA from the total RNA pool was modified from Franklin (1966) and Morris-Krsinich \& Hull (1983). This method separates dsRNA from ssRNA by exploiting differences in hydrophobicity and affinity for the microcrystalline cellulose matrix, CF11 (Whatman; GE Healthcare). After a 10 min centrifugation at $12000 \times g$, the aqueous phase was added to a CF11 column equilibrated with $16.5 \%$ EtOH/1× STE buffer. The column was washed 3 times with $1 \mathrm{ml}$ of $16.5 \% \mathrm{EtOH} / 1 \times \mathrm{STE}$ buffer, and the flow-through was discarded. To elute dsRNA, $800 \mu$ of $1 \times$ STE was added to the column, and the flow-through was collected in a microfuge tube. dsRNA was precipitated using isopropanol and sodium acetate (Sambrook et al. 1989). After an ethanol wash, the air-dried pellet was resuspended in $50 \mu \mathrm{l}$ of $1 \mathrm{mM}$ EDTA. A total of $5 \mu \mathrm{l}$ of the dissolved RNA were electrophoresed on a $1.5 \%$ ethidium bromide-stained agarose gel.

Partial cloning of the reo-like virus genome: The dsRNA pool from a putatively virus-infected hatchery crab (designated E41) was used to elucidate a portion of the virus genome following the methods outlined by Maan et al. (2007). Briefly, the dsRNA pool was precipitated using isopropanol and sodium acetate and concentrated by re-suspending in $5 \mu \mathrm{l}$ of deionized water. Approximately $500 \mathrm{ng}$ dsRNA was combined with 500 ng of an anchor primer (iSP9; see Table 1) contain-

Table 1. Oligonucleotides used in this study. RdRp: RNA-dependent RNA polymerase

\begin{tabular}{|llll}
\hline Oligonucleotide & Sequence $\left(5^{\prime}\right.$ to $\left.3^{\prime}\right)$ & Purpose & Source \\
\hline iSP9 & GACCTCTGAGGATTCTAAAC/ & Anchor-adapter & Maan et al. (2007) \\
& iSp9/TCCAGTTAGAATCC-OH & & \\
M15 -1 & GAGGGATCCAGTTTAGAATCCTCAGAGGTC & cDNA amplification & Maan et al. (2007) \\
M13 R & TGTAAAACGACGGCCAG & Sequencing & \\
BCRVFor & CAGGAAACAGCTATGAC & Sequencing & Present study \\
BCRVRev & TCAGTGTCTTCAGCTTTAGGTTG & Reovirus & Present study \\
CsAct1F & GTGTTGAGGCCTAGATTCG & Reovirus & Modified from Towle et al. (1997) \\
CsAct1R & GGGCAGCGGAACCTCTGGTT & Crab actin & Modified from Towle et al. (1997) \\
RdRp For & GGRGAYTACASCIRWTTTGAT & Crab actin & Culley et al. (2003) \\
RdRp Rev & TTYYTSAAGMGKMGTTGGTK & RdRp & Culley et al. (2003) \\
\hline
\end{tabular}


ing a phosphorylation on the $5^{\prime}$ terminus for ligating to the 3' end of the RNA strands, and a phosphoramidite spacer between 2 complementary halves allowing the primer to fold back and self-prime during cDNA synthesis (Integrated DNA Technologies; Maan et al. 2007). The ligation of the anchor primer to the dsRNA ends was carried out at $4^{\circ} \mathrm{C}$ overnight using $5 \mathrm{U}$ of T4 ligase in a final reaction volume of $10 \mu \mathrm{l}$, as per the manufacturer's instructions (Fermentas). Excess adaptors were removed using Sephadex G50 columns (Boehringer). The purified dsRNA with ligated anchor primers was precipitated using isopropanol/sodium acetate and resuspended in deionized water.

Prior to performing cDNA synthesis, the ligated dsRNA pool was denatured at $100^{\circ} \mathrm{C}$ for $2 \mathrm{~min}$ and placed immediately on ice. The $20 \mu \mathrm{l}$ reverse transcription reaction contained the following: $11 \mu \mathrm{l}$ denatured dsRNA, $5 \mathrm{mM} \mathrm{MgCl}_{2}, 1 \mathrm{mM}$ dNTP mix (Applied Biosystems), $15 \mathrm{U}$ avian myeloblastosis virus (AMV) reverse transcriptase, and $1 \times \mathrm{RT}$ buffer (Promega). The reaction was incubated at $37^{\circ} \mathrm{C}$ for $40 \mathrm{~min}$ and then at $40^{\circ} \mathrm{C}$ for $10 \mathrm{~min}$. PCR was carried out on $1 \mu \mathrm{l}$ cDNA using TaKaRa Ex Taq (Shiga) and primer 5-15-1 (Maan et al. 2007; Table 1). Thermocycling was as follows: $94^{\circ} \mathrm{C}$ for $2 \mathrm{~min}$; 30 cycles of $95^{\circ} \mathrm{C}$ for $15 \mathrm{~s}, 62^{\circ} \mathrm{C}$ for $30 \mathrm{~s}, 72^{\circ} \mathrm{C}$ for $2 \mathrm{~min}$, with a final extension at $72^{\circ} \mathrm{C}$ for $10 \mathrm{~min}$. Products were electrophoresed on a $1.5 \%$ ethidium bromide-stained agarose gel and visualized by fluorometric detection (Typhoon 9410; GE Healthcare).

Sterile pipet tips were used to bore out 3 sections of the gel in the area of low, medium, and high molecular weight bands. Each agarose stab was added to $20 \mu \mathrm{l}$ Milli-Q water and boiled for $3 \mathrm{~min}$ at $100^{\circ} \mathrm{C}$. A total of $1 \mathrm{\mu l}$ of liberated dsRNA from each stab was used in a second round of PCR as outlined in the paragraph above. The resulting products were electrophoresed on an ethidium bromide-stained gel and purified using the Geneclean ${ }^{\circledR}$ kit (Bio101). A total of $1 \mu$ of each of the purified pools was ligated into pGEM-T vector (Promega) overnight at $4^{\circ} \mathrm{C}$. Each ligation was transformed into JM109 (Stratagene). Approximately 50 white colonies were screened for inserts using PCR with M13 primers (Table 1). Each $25 \mu \mathrm{l}$ reaction contained the following: $0.8 \mathrm{U}$ Megafrag high fidelity Taq polymerase (Denville Scientific), $1 \times$ Megafrag buffer, $4 \mathrm{mM} \mathrm{MgCl} 2,1 \mathrm{mM}$ each dNTP (Applied Biosystems), $0.25 \mathrm{mg} \mathrm{ml}^{-1}$ bovine serum albumin (Idaho Technologies), $0.8 \mathrm{mM}$ each primer and molecular biology grade water to $25 \mu \mathrm{l}$. Thermocycling parameters were: $94^{\circ} \mathrm{C}$ for $2 \mathrm{~min} ; 30$ cycles of $95^{\circ} \mathrm{C}$ for $10 \mathrm{~s}, 60^{\circ} \mathrm{C}$ for $30 \mathrm{~s}$, $68^{\circ} \mathrm{C}$ for $2 \mathrm{~min}$; with a single $10 \mathrm{~min}$ extension at $68^{\circ} \mathrm{C}$. PCR products were analyzed on $1.5 \%$ ethidium bromide-stained agarose gels.

Partial cloning of viral RdRp gene: To elucidate additional sequence from the virus genome, degener- ate primers targeting the RdRp (Table 1) gene were employed (Culley et al. 2003). PCR was carried out with TaKaRa Ex Taq using an annealing temperature of $50^{\circ} \mathrm{C}$ and an extension time of $30 \mathrm{~s}$ to amplify a product of approximately 700 base pairs from the cDNA pool described above. This product was purified by precipitation, then ligated to pGEM-T as above and transformed into JM109 cells. Plasmids from 13 colonies were sequenced, as described below.

Sequencing and bioinformatic analysis: Plasmid inserts were PCR amplified with vector-specific primers (M13 F, M13 R) and amplicons precipitated with polyethylene glycol (PEG) (Sigma-Aldrich). Briefly, one volume of $20 \%$ PEG (containing $2.6 \mathrm{M} \mathrm{NaCl}$ ) was mixed with the PCR products and incubated at room temperature. After centrifugation at $12000 \times g$, the supernatant was discarded and the pellet resuspended in one volume of $70 \%$ ethanol and re-centrifuged at $12000 \times g$ for $5 \mathrm{~min}$. The pellet was resuspended in $30 \mu \mathrm{l}$ sterile water, and $2 \mu \mathrm{l}$ was used for sequencing. Sequencing was carried out using Big Dye version 3.1 reagents and analyzed on the ABI Prism 3130xl genetic analyzer (Applied Biosystems). Sequences were assembled into contigs using Sequencher ${ }^{\mathrm{TM}}$ (Gene Codes) and subjected to BLASTn and tBLASTx analyses (Altschul et al. 1990) to detect any similarity to deposited nucleotide or predicted protein sequences in GenBank.

RT-PCR virus detection assay: Primers (BCRVFor and BCRVRev; Table 1) were designed to amplify a $483 \mathrm{bp}$ region of the $1.2 \mathrm{~kb}$ genome segment. Primers were tested in PCR reactions using naïve genomic crab DNA (no amplicons were produced; data not shown). Furthermore, to verify which segment of dsRNA was targeted by the RT-PCR assay, gel stabs were collected from 7 different regions of the electrophoresed dsRNA genome and subjected to RT-PCR using $1 \mu \mathrm{l}$ of template (prepared as described in 'Partial cloning of viral RdRp gene') and 20 cycles of PCR. Sensitivity of the assay was determined to be $7.5 \mathrm{pg}$ of input RNA based on RT-PCR analysis (30 cycles) of a 10-fold serial dilution of DNAse-treated total RNA extracted from a reovirus-positive crab (determined by a dsRNA preparation as described above). To generate total RNA from tissue samples for screening by RT-PCR, tissue disruption and TRIzol ${ }^{\circledR}$ extraction were carried out as described above. Isopropanol precipitation was performed on the RNA fraction, and the resulting pellet was resuspended in $50 \mu \mathrm{l}$ of $1 \mathrm{mM}$ EDTA. RNA purity and concentration were determined using the Nanodrop Spectrophotometer (Nanodrop Technologies). RNA was DNAse treated (Fermentas) prior to reverse transcription. RT was carried out as described above using $75 \mathrm{ng}$ of RNA and with the addition of $50 \mathrm{ng}$ random hexamers (Invitrogen). PCR was performed as 
outlined above for Megafrag, using $2 \mu \mathrm{l}$ of cDNA, BCRVFor, and BCRVRev primers, an annealing temperature of $61^{\circ} \mathrm{C}$ and an extension time of $30 \mathrm{~s}$. To assess quality of cDNA, each preparation was also subjected to PCR amplification using primers (CsActF1 and CsActR1; Table 1) modified from Towle et al. 1997 to amplify the blue crab actin gene.

Virus transmission study. Virus preparation from blue crab homogenate: A virus-infected crab was chosen for a crude viral preparation based on analysis of a dsRNA gel as described above. Approximately $300 \mathrm{mg}$ of tissue was disrupted in $6 \mathrm{ml}$ of $15 \mathrm{ppt}$ filter-sterilized artificial seawater using a homogenizer (Ultra-turrax T8; IKA). After 30 s, no multicellular pieces were visible by light microscopy. A slow centrifugation step was used $(1500 \times g$ for $5 \mathrm{~min})$ to pellet debris. The supernatant was filtered through a $0.45 \mu \mathrm{m}$ filter (later virus preparations were filtered through $0.2 \mu \mathrm{m})$, and the resulting filtrate was kept on ice until injection.

Passage of reovirus to naïve, hatchery-reared animals: Two preliminary trials were conducted to demonstrate passage of the virus using blue crabs that were grown from the larval stage in COMB's biosecure recirculating hatchery (Zmora et al. 2005). Males and females from 60 to $100 \mathrm{~mm}$ carapace width were used as recipients for initial passage experiments. Standard rearing and infection conditions were 20 ppt salinity (artificial seawater) and 22 to $24^{\circ} \mathrm{C}$. The filtered homogenate $(20 \mu \mathrm{l}$, representing $<1 \mathrm{mg}$ donor tissue) was injected into recipients $(\mathrm{n}=5$ for Trial $1 ; \mathrm{n}=11$ for Trial 2) after surface sterilizing the injection site with ethanol at the base of the swimming leg. The virus preparation from Trial 1 was stored at $-80^{\circ} \mathrm{C}$ for $5 \mathrm{mo}$ and re-tested for the ability to cause death of diseasefree blue crabs (Trial 2). Five non-injected control crabs were used in Trial 1, while 5 saline-injected crabs were used in Trial 2 in order to mimic stress from handling. A time course experiment was then conducted by injecting 10 naïve animals with $10 \mu \mathrm{l}$ of crude virus preparation. Experimental crabs were sacrificed at intervals from Day 3 to 16 by chilling on ice. Selected tissues (muscle and hypodermis, gill, hepatopancreas) were fixed in glutaraldehyde in preparation for electron microscopy. The remaining crab tissue was stored at $-20^{\circ} \mathrm{C}$ for later assessment of viral RNA.

Light and electron microscopy: Crabs were dissected $3,6,9,12,13,15$, and 16 d post inoculation. Tissues were preserved in $1 \%$ glutaraldehyde $+4 \%$ formaldehyde (1G4F) for light microscopy and in Millonig's phosphate buffered $2.5 \%$ glutaraldehyde (Millonig 1976) for electron microscopy. Tissues from all crabs preserved in 1G4F were processed for histological examination by standard methods (Johnson 1980, Howard \& Smith 1983).
Tissues from the crab dissected $16 \mathrm{~d}$ post inoculation were processed for transmission electron microscopy. After primary fixation, tissues were washed with buffer and post fixed in $2 \%$ osmium tetroxide in $2 \mathrm{M}$ Millonig's phosphate buffer for $1 \mathrm{~h}$ at room temperature. Tissues were rinsed in buffer and dehydrated in a series of ethanols, infiltrated and embedded in Spurr's low viscosity embedding formula epoxy resin, and sectioned using a Leica UC6 ultramicrotome. Thick sections were stained with $1 \%$ toluidine blue in $1 \%$ boric acid and examined for virus. Samples were thin sectioned at $70 \mathrm{~nm}$ (silver/gold) mounted on 250 mesh copper grids, air dried, and stained using Reynolds' (1963) lead citrate for $1.5 \mathrm{~min}$. Thin sections were examined and photographed using a Zeiss EMI OCA at 60 to $80 \mathrm{Kv}$.

Negatives of electron micrograph images were scanned and digitized, and the diameters of apparent virus particles were measured using ImageJ software (ImageJ 1.42q; Abramoff et al. 2004). The largest diameters measured were interpreted to represent equatorial sections of viruses. Image J was also used to measure cross-sections and lengths of other subcellular structures in virus-infected cells.

\section{RESULTS}

\section{Physicochemical enrichment of a putative reo-like virus genome}

Both healthy $(\mathrm{n}=5)$ and dead/dying $(\mathrm{n}=6)$ peeler crabs were collected from a commercial soft shell crab production facility. None of the crabs showed obvious signs of physical injury. To identify crabs that may have died with high bacterial loads, DNA was extracted from crab muscle and hypodermis and used as template for amplification of bacterial rRNA genes using 'universal' primers designed to amplify $16 \mathrm{~S}$ rRNA genes (Lane 1991). One crab that failed to generate a bacterial $16 \mathrm{~S}$ amplicon (indicating a low bacterial DNA content; data not shown) and was thus a candidate for virus-related mortality was chosen for further analysis by dsRNA enrichment. Total RNA was extracted from hypodermis, hepatopancreas, and muscle (which contained overlying hypodermis). Corresponding samples of a healthy soft shell crab were also processed in the same manner. Crude RNA extracts were subjected to differential precipitation with $\mathrm{LiCl}$ (Diaz-Ruiz \& Kaper 1978), to enrich for dsRNA. The dsRNA preparation from the dying crab showed numerous bands ranging from approximately 1 to $4 \mathrm{~kb}$, while the dsRNA preparation from the healthy crab showed a weak background smear but no dsRNA banding (Fig. 1A). When dsRNA from the dying crab 

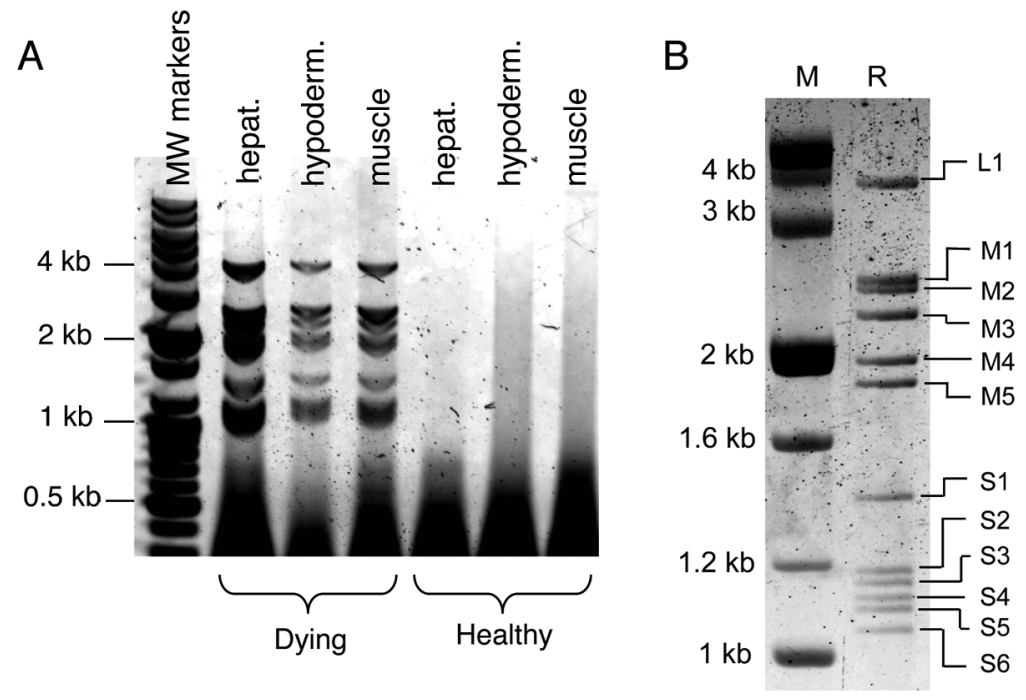

Fig. 1. Callinectes sapidus. Visualization of an apparent virus genome by enrichment of double-stranded RNA (dsRNA). (A) Agarose gel electrophoresis of dsRNA enriched by $\mathrm{LiCl}$ precipitation. Lane 1: $100 \mathrm{bp}$ DNA molecular weight (MW) size marker; Lanes 2 to 4: total RNA extracted from hepatopancreas, muscle, and hypodermis of a dying crab; Lanes 5 to 7: RNA extracted from hepatopancreas, muscle, and hypodermis of a healthy crab. (B) Electropherogram of dsRNA enriched by CF11 chromatography. Lane 1: 100 bp DNA marker (M); Lane 2: blue crab reo-like virus (R)
Tissues of the crab displaying putative reovirus dsRNA segments were fixed and processed for histology. Cytoplasmic inclusions consistent with a reo-like virus were observed in hemocytes within gill tissue (G. Messick, data not shown). The dsRNA enrichment method was applied to the 10 remaining crabs in this initial study: 5 additional mortalities and 5 apparently healthy crabs. Of the 5 mortalities, 4 showed the same dsRNA banding as seen in Fig. 1; among the 5 live crabs, none showed virus-like dsRNA bands. These data are summarized in Table 2. Ammonia and nitrite levels were periodically tested during the study. Nitrite remained below $0.011 \mathrm{mg}^{-1}$ in all but one sample (rising to $0.018 \mathrm{mg} \mathrm{l}^{-1}$ once), and ammonia stayed below $0.12 \mathrm{mg} \mathrm{l}^{-1}$, save for a single reading of 0.25 in the same sample with highest nitrite. There were no mortalities during or immediately after this spike in nitrogen. was more efficiently enriched using CF11 affinity chromatography and analyzed by extended agarose gel electrophoresis, an image of 12 bands was visualized. The bands co-migrated with the DNA ladder at apparent sizes of 1.1 to $4 \mathrm{~kb}$, with an electrophoretic pattern of $1 / 5 / 6$ (Fig. 1B).

Table 2. Callinectes sapidus. Prevalence of putative reo-like virus in captive (soft shell systems, hatchery) and wild populations of blue crab as determined by presence of double-stranded RNA (dsRNA) banding. Baltimore: MD, USA; Tilghman: MD, USA; COMB: Center of Marine Biotechnology

\begin{tabular}{|lrc|}
\hline Source of crabs & $\begin{array}{c}\text { No. } \\
\text { tested }\end{array}$ & $\begin{array}{c}\text { dsRNA+ } \\
(\%)\end{array}$ \\
\hline 2007 soft shell systems & & \\
Baltimore, flow through, healthy & 5 & 0 \\
Baltimore, flow through, dead/dying & 6 & 83 \\
& & \\
2008 soft shell systems & 3 & 0 \\
Baltimore, flow through, live & 4 & 50 \\
Baltimore, flow through, dead & 12 & 58 \\
Florida Gulf coast, recirculating, dead & 9 & 78 \\
Tilghman, flow through, dead & 10 & 80 \\
Tilghman, transfer to COMB, dead & & \\
& 42 & 0 \\
2008 fresh harvest & 16 & 0 \\
Inter-molt, live & & \\
Pre-molt, live & & \\
& 12 & 50 \\
2006-2008 archived mortalities & & \\
COMB recirculating hatchery & & \\
\hline
\end{tabular}

\section{Evidence of virus in additional soft shell systems and in a crab hatchery}

The dsRNA enrichment assay was used to assess whether the high prevalence of a putative reo-like virus observed in crabs dying in the Baltimore facility was representative of crabs dying in other places and times (summarized in Table 2). In 2008, 7 crabs from the original soft shell facility were investigated, and it was found that virus-like dsRNA was present in 2 of 4 dead crabs but in none of 3 live crabs. Two additional soft shell production facilities were investigated in 2008. A recirculating soft shell facility on the Gulf coast of Florida provided 12 blue crabs that died before or during molting. Of these, 7 displayed the same dsRNA banding seen in Fig. 1. A flow-through system on the eastern shore of Chesapeake Bay (Tilghman) provided 9 crabs that died in the molting process; of these, 7 were positive for the virus. An additional 10 live premolt crabs were also collected from the Tilghman facility, brought to $\mathrm{COMB}$, and maintained in isolated individual tanks. All 10 crabs died prior to or during the molting process, and 8 displayed the familiar virus-like dsRNA banding.

Thus far, all crabs investigated had been maintained in captivity where they suffered high mortality. Therefore, inter- and pre-molt fresh harvest crabs were also studied; 2 samples were obtained from the same region of the Chesapeake Bay from which animals were 
obtained for the 2007 and 2008 soft shell system studies (Table 2). Of 42 live inter-molt crabs assessed, none had dsRNA banding. Similarly, analysis of 16 freshly caught, pre-molt crabs also revealed no evidence of virus dsRNA.

The wild-harvest broodstock in the blue crab hatchery at COMB was also investigated. These mature, mated females are collected yearly from the lower Chesapeake Bay and are maintained in closed recirculating aquaculture until needed for larvae production. Cumulative mortalities among wild broodstock may exceed $50 \%$. An analysis of 12 archived broodstock mortalities (from 2006 to 2008) revealed that 6 carried dsRNA indistinguishable to that seen in Fig. 1 (Table 2, bottom panel).

\section{Experimental infections with the putative virus}

To investigate whether the putative virus could be passaged and cause blue crab mortality, a filtered homogenate of infected muscle and hypodermis was injected into 5 naïve, hatchery-reared juveniles. Putative virus-injected crabs died at Day 10 (1 crab), Day 12 (1 crab), and Day 13 (3 crabs) post-injection. None of the un-injected control crabs died over this time, and were sacrificed at Day 14. Upon analysis of dsRNA, each of the putative virus injected crabs displayed reolike dsRNA bands, while the control crabs showed no dsRNA banding (Trial 1, Table 3). The virus preparation was re-tested after storage at $-80^{\circ} \mathrm{C}(5 \mathrm{mo})$ for the ability to cause death of disease-free blue crabs. When injected into 11 naïve crabs (Trial 2; Table 3), all died within $15 \mathrm{~d}$. Injections $(\mathrm{n}=5)$ of sterile saline did not result in crab mortality.

To assess how rapidly dsRNA appears during an experimental infection with the virus, a time course study was conducted, in which 10 naïve crabs were injected with virus preparations and then sacrificed at

Table 3. Callinectes sapidus. Blue crab mortality following injection of putative reo-like virus. na: not applicable; nt: not tested

\begin{tabular}{|c|c|c|c|c|}
\hline Injection & $\mathrm{N}$ & $\begin{array}{l}\text { Mortality } \\
\text { (\%) }\end{array}$ & $\begin{array}{c}\text { Days to } \\
\text { death }\end{array}$ & $\begin{array}{c}\text { Virus } \\
\text { RNA } \\
\text { prevalence }\end{array}$ \\
\hline \multicolumn{5}{|l|}{ Trial 1} \\
\hline Virus filtrate & 5 & 100 & 10 to 13 & 100 \\
\hline No injection & 5 & 0 & na & 0 \\
\hline \multicolumn{5}{|l|}{ Trial 2} \\
\hline Virus filtrate & 11 & 100 & 9 to 16 & nt \\
\hline Saline injection & 5 & 0 & na & nt \\
\hline
\end{tabular}

intervals from Day 0 to 16. As shown in Fig. 2, within $3 \mathrm{~d}$ of injection (earliest sampling) crabs displayed obvious virus dsRNA, particularly in gills (Fig. 2A) as compared to muscle (Fig. 2B). The amount of virus dsRNA increased through Days 13 and 16, when crabs were moribund and dying.

Crabs dissected 9, 12, 13, 15, and 16 d post inoculation demonstrated histological characteristics consistent with varying degrees of infection by reo-like virus infections (Johnson 1977, 1984). Reo-like virus infections were identified based on morphologic similarities published by Johnson (1977, 1984), which include angulated, basophilic, Feulgen negative, cytoplasmic inclusions in hemocytes (Fig. 3A). Also apparent in the crab dissected $16 \mathrm{~d}$ post inoculation were necrotic hemocytes and a few nodule formations due to host response to the viral foreign bodies found in gill and epidermal tissues.

Electron microscopic examination of infected gill tissue revealed that many of the hemocytes within the tissue appeared to have degenerating cell membranes and were filled with apparent virus-like particles $\sim 55 \mathrm{~nm}$ in diameter. Virus-infected cells also contained numerous filamentous structures, $\sim 30 \mathrm{~nm}$ in width, but of highly variable lengths (some exceeding $800 \mathrm{~nm}$ ) (Fig. 3B).

A
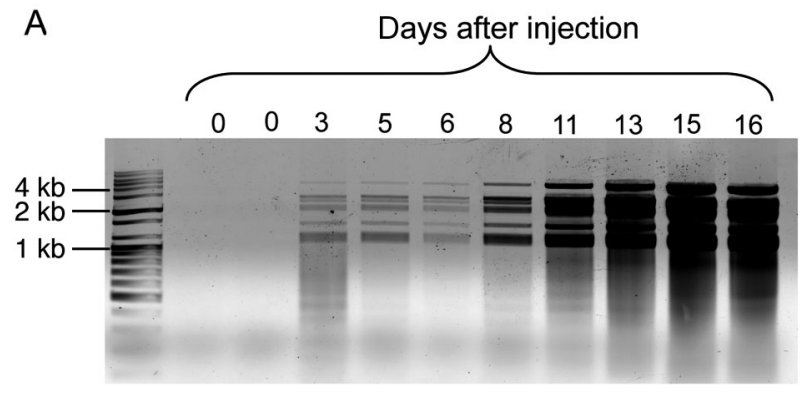

B

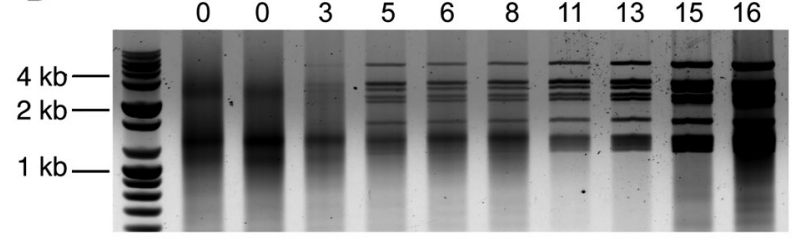

Fig. 2. Callinectes sapidus. Passage of virus double-stranded RNA (dsRNA) to uninfected hatchery-reared crabs. Agarose gel analysis of a time course of dsRNA appearance after injection. Day 0 (duplicate samples) is pre-injection; Day 3 is the earliest sampling point. (A) dsRNA isolated from gills. (B) dsRNA isolated from leg muscle and hypodermis. Equivalent amounts of tissue are represented in each panel 

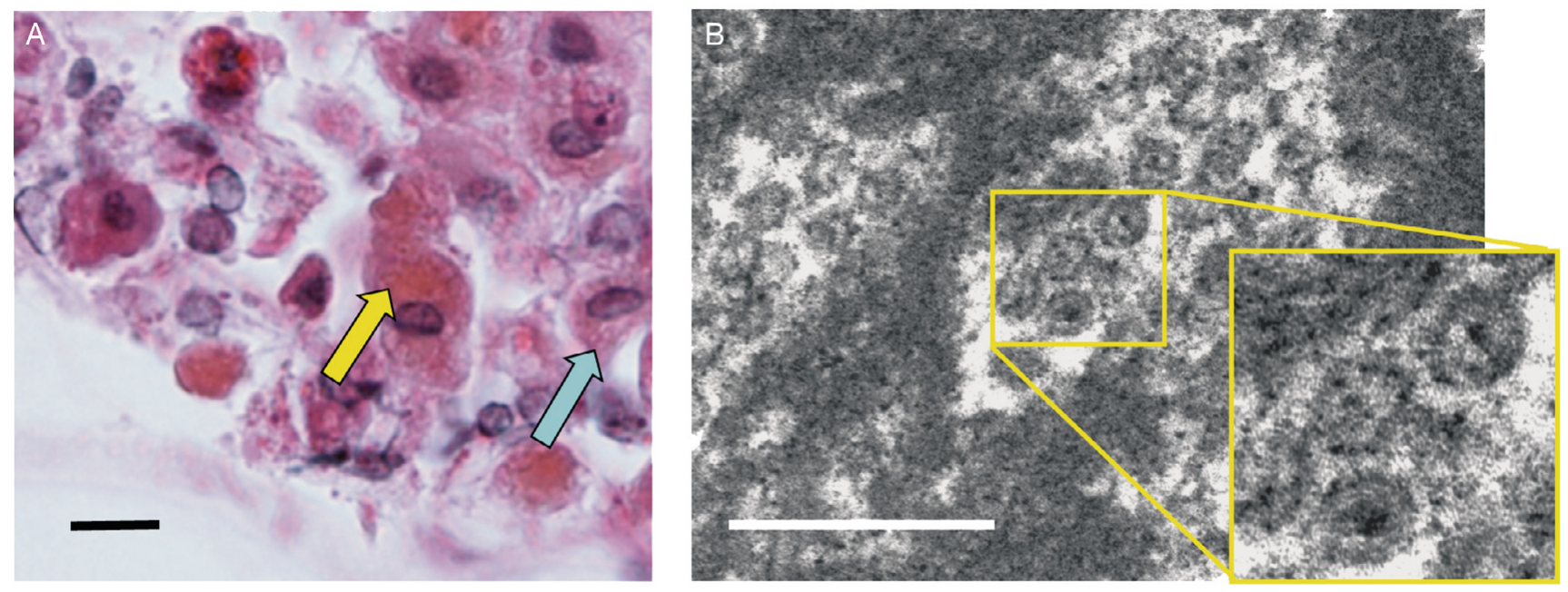

Fig. 3. Callinectes sapidus. Microscopy of putative reo-like virus-infected tissues. (A) Hematoxylin and eosin stain. Many cells have increased cytoplasmic volume (yellow arrow) indicative of virus inclusions compared to more normal cytoplasmic volume (blue arrow). Scale bar $=10 \mu \mathrm{m}$. (B) Electron microscopy. Hemocyte filled with virions and filamentous material. Inset: enlarged view of virions. Scale bar $=0.25 \mu \mathrm{m}$

\section{Partial nucleic acid sequence of the reo-like virus genome}

A full-length cDNA copy of the $1.2 \mathrm{~kb}$ segment of dsRNA was cloned as described above (Maan et al. 2007). Sequencing of the clone revealed an insert of 1233 nucleotides, which has been deposited in GenBank under accession no. HM014010. The longest open reading frame in the sequence encoded a 323 amino acid protein with a predicted molecular weight (MW) of $35.45 \mathrm{kDa}$ and isoelectric point (pI) of 6.16. BLAST analyses of the peptide sequence revealed no significant similarities at either the nucleotide or predicted amino acid sequence levels against the non-redundant GenBank nucleotide database or the virus protein database. Computational predictions of protein function indicated similarity to glycosyltransferases ( $p=96.7 \%$; Cai et al. 2003; Vector Machine classification).

Using conserved, degenerate primers designed to amplify a segment of the RdRp gene (Culley et al. 2003), a PCR amplicon was obtained from cDNA prepared from viral RNA. Sequencing of 13 clones produced a consensus contig of 729 nucleotides (deposited in GenBank under accession no. HM014011), encoding a continuous reading frame of 243 amino acids. BLASTx analysis of the encoded/predicted polypeptide revealed 100\% amino acid identity over a 48 amino acid region to a GenBank entry for a partial RdRp clone from a reovirus of the mud crab Scylla serrata (EF523476). When examined at the nucleotide level, conservative substitutions were observed in 26 codons, including Leu and Arg codons, which have 6 possible codons (Fig. 4).

\section{Development of an RT-PCR assay targeting a segment of the virus genome}

Primers were designed to target a $438 \mathrm{nt}$ portion of the cloned $1.2 \mathrm{~kb}$ segment. When tested against genomic DNA and reverse-transcribed RNA of an uninfected crab, these primers produced no products; when tested on reverse-transcribed RNA of crabs harboring dsRNA, the expected 438 bp product was obtained (Fig. 5A, Lanes 4 and 5). Verification that the RT-PCR assay targeted the $1.2 \mathrm{~kb}$ dsRNA band was accomplished by conducting the assay on individual dsRNA bands cored out of agarose gels (data not shown). Assay sensitivity was estimated by dilution of total RNA extracted from an infected crab (Day 16 in Fig. 2) prior to the reverse-transcription step. The assay produced a visible amplicon from as little as $7.5 \mathrm{pg}$ of total RNA (Fig. 5B). Based on this sensitivity, we chose to use $5 \mathrm{ng}$ total RNA (667-fold higher than the limit of detection) for routine RT-PCR assays.

The RT-PCR assay was used to screen wild-caught hatchery broodstock in early 2009, after several broodstock females (maintained at $15^{\circ} \mathrm{C}$ ) died in the aquaculture center. Hemolymph was withdrawn (nonlethally) from the remaining 28 crabs; total RNA was extracted and subjected to the RT-PCR assay. RNA from 8 crabs produced the amplicon expected for reolike virus. In the ensuing $5 \mathrm{wk}, 7$ of these PCR-positive individuals died, while none of the PCR-negative individuals died. By Fisher's exact test, this has statistical significance with $\mathrm{p}<0.0001$. 

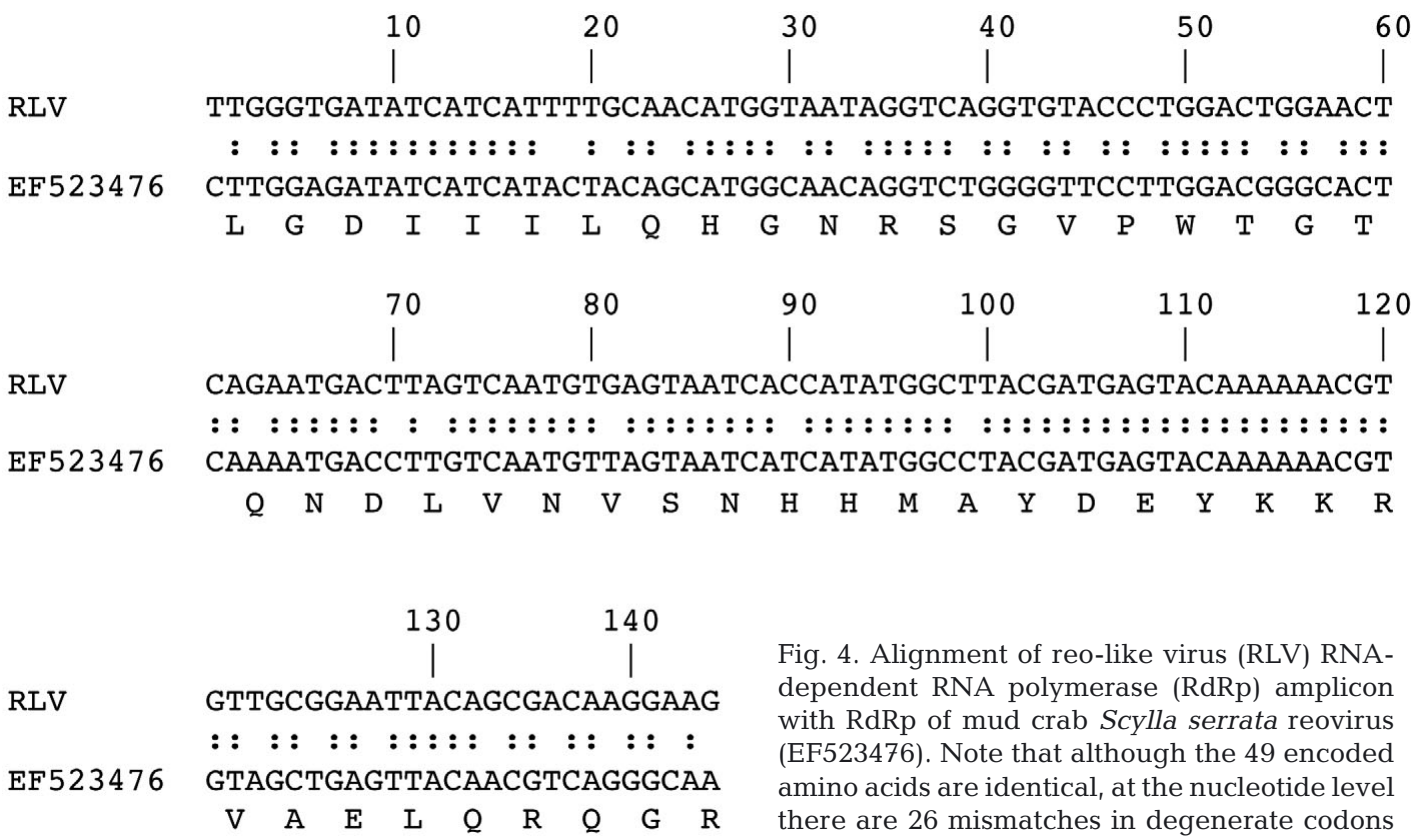

Fig. 4. Alignment of reo-like virus (RLV) RNAdependent RNA polymerase (RdRp) amplicon with RdRp of mud crab Scylla serrata reovirus (EF523476). Note that although the 49 encoded amino acids are identical, at the nucleotide level there are 26 mismatches in degenerate codons
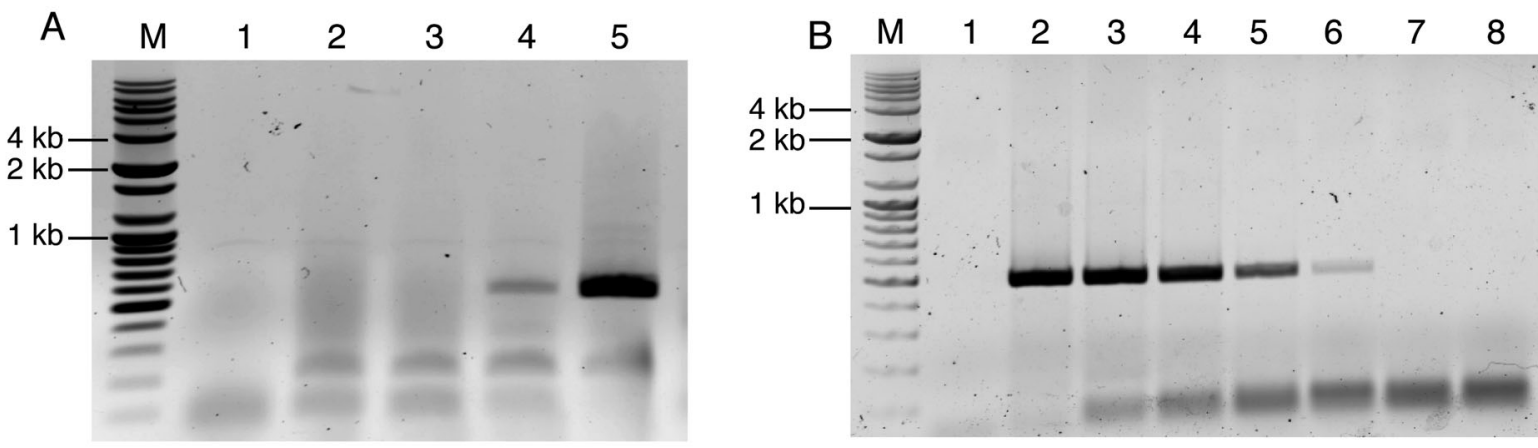

Fig. 5. Ethidium bromide-stained agarose gel depicting the reo-like virus reverse transcription-PCR assay. (A) Specificity of the assay on different templates. Lane 1: no template; Lane 2: RNA of uninfected Callinectes sapidus crab; Lane 3: DNA of uninfected

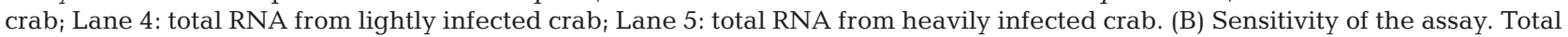
RNA was extracted from a virus-positive crab (determined by gel analysis of the dsRNA), and a 10-fold serial dilution was prepared. Values indicate the amount of total RNA from the infected crab that was reverse transcribed. Lane M: $100 \mathrm{bp}$ marker;

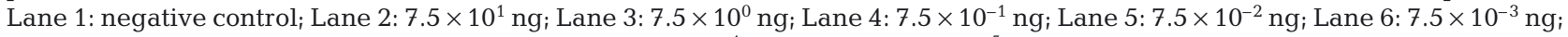

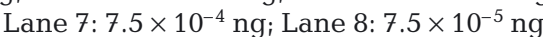

\section{DISCUSSION}

The present study demonstrates the utility of exploiting the physicochemical properties of dsRNA as an initial step in identifying a virus associated with blue crab mortality. In this instance, a dsRNA enrichment procedure was used to visualize the dsRNA genome of a reolike virus. Findings from one crab provided the basis for screening of more than 100 additional crabs. Though useful as a first step, a genome-targeted approach is not sufficient to establish the presence of a virus. Subsequent investigations included re-infection of hatchery-reared crabs with virus preparations, his- tological assessments, electron microscopy, and sequencing part of the virus genome. The reo-like virus was found to be highly prevalent in captive blue crabs in various soft shell production facilities as well as in wild-caught broodstock held in a recirculating research aquaculture operation. The association of reolike virus with blue crab mortality is more than circumstantial, when injected, the virus was $100 \%$ fatal. Two caveats are warranted in interpreting this finding: First, we lack a method to quantify the number of infectious viruses represented by injections; the development of a system to titer viruses, like that for PaV1 (Li \& Shields 2007) would be a significant advance. 
Second, we note that a more rigorous control, of injecting non-infected homogenized crab tissue, was not conducted in parallel with the virus injection. In a separate study, however, similarly prepared homogenates from a crab assessed to be free of the putative virus did not cause mortality or the appearance of dsRNA.

A sensitive RT-PCR assay was developed that allows the virus to be detected in RNA from small quantities of hemolymph. Using this methodology to (non-lethally) screen wild broodstock, $86 \%$ of those positive for the virus died within a few weeks. The ability to screen crabs for virus dsRNA by hemolymph sampling was facilitated by the fact that the reo-like virus proliferates in hemocytes. The virus is also abundant in hypodermal tissue, thereby making it feasible to assess crabs by removal (autotomy) of a leg for dsRNA extraction.

The hemocyte and hypodermal localization (ectodermally and mesodermally derived tissues) are also features of the reo-like virus reported by Johnson (1977, 1984). Similar to the virus described here, reo-like virus is rapidly fatal to blue crab, is highly prevalent in captive blue crabs, and has an icosahedral virion of 55 to $60 \mathrm{~nm}$ (Johnson 1983, 1984). Thus, there is a strong indication that reo-like virus and the virus we describe are synonymous. Our electron micrographs of cells containing reo-like virus profiles also show tubular structures $\sim 30 \mathrm{~nm}$ across, of variable lengths up to $800 \mathrm{~nm}$. In these respects, they are similar to those reported by Johnson (1984), who interpreted them to be evidence of a co-infecting rhabdovirus. While Jahromi (1977) also reported the presence of a rhabdovirus (in the absence of other viruses) in blue crab, the $30 \mathrm{~nm}$ wide virions he described had less variable lengths, of approximately $115 \mathrm{~nm}$, which is more consistent with rhabdovirus morphology as a whole. Based on this difference and a growing body of reovirus literature, it is likely that the tubules observed by Johnson and ourselves were not rhabdoviruses, but were cellular manifestations of reo-like virus replication. Similar structures 18 to $68 \mathrm{~nm}$ in diameter and with highly variable lengths are associated with numerous reoviruses in diverse hosts (Moss \& Nutall 1995). Recombinant expression of a single virus protein, NS1, of the well-studied bluetongue virus can cause the appearance of such tubules (Roy \& Noad 2006).

The reo-like virus in blue crab has a dsRNA genome of 12 segments in a 1/5/6 pattern (Fig. 1B). Three other crab reoviruses are reported to have similar $1 / 5 / 6$ genomes of 12 dsRNA segments: W2 virus of Carcinus mediterraneus (Mari \& Bonami 1988), $\mathrm{P}$ virus of Macropipus depurator (Montanie et al. 1993), and the reovirus of Eriocheir sinensis (EsRV905; Zhang et al. 2004). These 3 viruses are proposed to constitute a new genus, termed Cardoreovirus (Attoui \& Mertens 2005,
Mayo \& Haenni 2006). The reovirus of the mud crab Scylla serrata (MCRV) (Weng et al. 2007) has a 13 segment dsRNA genome with a banding pattern of 1/5/7, in which the smallest 2 segments co-migrate on electrophoretic gels.

It is notable that the partial RdRp sequence obtained from the blue crab reo-like virus encodes a peptide that is $100 \%$ identical to part of the predicted MCRV RdRp (GenBank EF523476). In contrast, an attempt to align the partial RdRp sequence from the reo-like virus with the RdRp of Eriocheir sinensis produced an alignment with only $18 \%$ amino acid (aa) identity over a 33 aa region (not shown). The weak similarity of blue crab reo-like virus RdRp to the RdRp of E. sinensis suggests the blue crab virus may not be in the Cardoreovirus genus. The $1.2 \mathrm{~kb}$ segment of the reo-like virus genome that was fully sequenced (and is targeted by the RT-PCR assay described herein) does not have significant similarity to any sequences in GenBank. Complete sequencing of the entire blue crab reo-like virus genome should greatly assist in placing the virus within a taxonomic clade.

The high prevalence $(>50 \%)$ of reo-like virus in crabs dying in multiple soft shell facilities suggests that it contributes widely to mortality in these settings. Mortality of blue crabs in soft shell facilities is typically $25 \%$ or more, and has been attributed to poor water quality and handling stress (Chaves \& Eggleston 2003). Over the past $15 \mathrm{yr}$, the soft shell crab industry in the United States had an average annual dockside value of $\$ 5$ million (NOAA, NMFS data). If half of the mortality in the industry is associated with reo-like virus, then an annual loss of $\$ 625000$ may be associated with this single disease agent. If not the sole cause, then reo-like virus may be synergistic with other stresses to cause mortalities. Handling, crowding, and poor water quality are known to cause immune suppression of invertebrates (e.g. Le Moullac \& Haffner 2000, Lacoste et al. 2002), which may allow latent infections of diseasecausing organisms to proliferate. The present study, having established a strong association between a putative reovirus and captive crab mortality, and having developed tools to monitor the virus, is a first step in devising management approaches to reduce virusrelated mortality.

The tools and approach described herein can be applied to the question of whether diseases are a factor in blue crab population fluctuations. Reo-like virus is only one of dozens of blue crab pathogens described (Shields \& Overstreet 2007), and one of at least 3 viruses with RNA genomes (Jahromi 1977, Johnson 1983). Large-scale virus prevalence investigations have been hampered by the labor and time required to assess virus infections by histology and electron microscopy. 
Taking a physicochemical approach to virus genome discovery should facilitate the description of crustacean viruses and accelerate development of tools to study them. The dsRNA enrichment method has the potential to enrich not only the genomic material of encapsidated dsRNA viruses such as reoviruses and birnaviruses, but also the replicative stages of ssRNA virus genomes (Valverde et al 1990). In fact, during our screening of wild crabs for reo-like virus, dsRNA banding patterns suggestive of additional diverse virus genomes were observed. Additional studies are underway to ascertain whether these findings reflect bona fide viruses.

The absence of visible viral dsRNA from freshly harvested crabs (both inter-molt and pre-molt) is remarkably different from the high incidence observed in dead/dying captive crabs. Some of the possible explanations for this discrepancy may be: (1) freshly harvested crabs may harbor cryptic infections of reo-like virus that intensify in captivity; (2) reo-like virus prevalence may be low in crabs when they are trapped and brought into captivity, but injuries and cohabitation result in virus transmission between individuals; or (3) prevalence of the virus may be underestimated in the fishery-dependent collections used in this study, since moribund infected crabs will be less likely to be caught in traps or on trotlines.

Special mention is warranted on the topic of cannibalism, which is a recognized route of infection for reolike virus (Johnson 1978) and other crustacean viruses (e.g. TSV in shrimp; Hasson et al. 1995). The diet of wild blue crab includes an appreciable proportion of conspecifics, especially smaller crabs, those in the molting process (Laughlin 1982, Hines et al. 1990), and, presumably, individuals that are moribund as a result of disease. In our experimental infections, reovirusinfected crabs become lethargic 2 to $3 \mathrm{~d}$ prior to death, which would make them susceptible to cannibalism.

Only through further study of the prevalence, transmission, and geographic distribution of the blue crab reo-like virus will it become clear what role it plays in natural mortality. A better understanding of the role of the virus in mortality of both captive and wild blue crabs will benefit both the hard crab and soft shell fishing industry throughout the blue crab range across 2 hemispheres. The development of the tools described here (dsRNA enrichment and a specific RT-PCR assay) should facilitate these studies and stimulate additional research. Furthermore, the generalized approach for enriching dsRNA may be highly useful for identifying additional RNA virus genomes.

Acknowledgements. The authors express their gratitude to Sue Tyler, of NOAA Oxford Lab, for electron microscopy, Kelly Cox of Phillips Wharf Environmental Center (Tilghman, MD) and Ronnie Day (St. Marks, FL) for providing soft shell aquaculture blue crabs. We also thank Dr. Allen Place of the Institute of Marine and Environmental Technolgy, University of Maryland Center for Environmental Science (IMET/ $\mathrm{UMCES}$ ), for his helpful suggestions and critical reading of the manuscript. This research was supported by a NOAA Chesapeake Bay Program grant (NA17FU2841) to Y. Zohar (IMET, University of Maryland Baltimore County), a NOAA/ NOS contract (EA133C07RQ0669) to E.J.S., NOAA-Educational Partnership Program (LMRCSC) to funding to IMET (NA06OAR4810163 to R.J.), and Maryland SeaGrant (NA050AR417042) to E.J.S. This is publication 4467 of the University of Maryland Center for Environmental Science.

\section{LITERATURE CITED}

Abramoff MD, Magelhaes PJ, Ram SJ (2004) Image processing with ImageJ. Biophoton Int 11:36-42

Ahlquist P (2006) Parallels among positive strand RNA viruses, reverse-transcribing viruses, and double-stranded RNA viruses. Nat Rev Microbiol 4:371-382

Altschul SF, Gish W, Miller W, Myers EW, Lipman DJ (1990) Basic local alignment search tool. J Mol Biol 215:403-410

Ary RD Jr, Poirrier MA (1989) Acute toxicity of nitrite to the blue crab (Callinectes sapidus). Prog Fish-Cult 51:69-72

Attoui H, Mertens PPC (2005) Template for taxonomic proposal to the ICTV Executive Committee to create a new genus in an existing family ICTV document code 2005. 243V.04. Available at: http://talk.ictvonline.org/files/ ictv_official_taxonomy_updates_since_the_8th_report $/ \mathrm{m} /$ vertebrate-2008/231.aspx (accessed 8 Nov 2010)

- Blankenship LE, Yayanos AA (2005) Universal primers and PCR of gut contents to study marine invertebrate diets. Mol Ecol 14:891-899

Butler MJ, Behringer DC, Shields JD (2008) Transmission of Panulirus argus virus 1 (PaV1) and its effect on the survival of juvenile Caribbean spiny lobster. Dis Aquat Org 79:173-182

Cai CZ, Han LY, Ji ZL, Chen X, Chen YZ (2003) SVM-Prot: web-based support vector machine software for functional classification of a protein from its primary sequence. Nucleic Acids Res 31:3692-3697

Chaves JC, Eggleston DB (2003) Blue crab mortality in the North Carolina soft shell industry: biological and operational effects. J Shellfish Res 22:241-250

Chesapeake Bay Stock Assessment Committee (2009) Chesapeake Bay blue crab advisory report. NOAA Chesapeake Bay Office. Available at: http://chesapeakebay.noaa.gov/ images/stories/pdf/BlueCrabAdvisoryReport2009.pdf (accessed 8 Nov 2010)

Culley AI, Lang AS, Suttle CA (2003) High diversity of unknown picorna-like viruses in the sea. Nature 424: 1054-1057

- Diaz-Ruiz JR, Kaper JM (1978) Isolation of viral doublestranded RNA using a $\mathrm{LiCl}$ fractionation procedure. Prep Biochem 8:1-13

Franklin RM (1966) Purification and properties of the replicative intermediate of the RNA bacteriophage R17. Proc Natl Acad Sci USA 55:1504-1511

Fujimura T, Solorzano A, Esteban R (2005) Native replication intermediates of the yeast 20S RNA virus have a singlestranded RNA backbone. J Biol Chem 280:7398-7406

> Hasson KW, Lightner DV, Poulos BT, Redman RM, White BL, Brock JA, Bonami JR (1995) Taura syndrome in Penaeus vannamei: demonstration of a viral etiology. Dis Aquat Org 23:115-126

Hewitt DA, Lambert DM, Hoenig JM, Lipcius RN, Bunnell DB, 
Miller TJ (2007) Direct and indirect estimates of natural mortality for blue crab. Trans Am Fish Soc 136:1030-1040

Hines AH, Haddon AM, Wiechert LA (1990) Guild structure and foraging impact of blue crabs and epibenthic fish in a subestuary of Chesapeake Bay. Mar Ecol Prog Ser 67: 105-126

Howard DW, Smith CS (1983) Histological techniques for marine bivalve mollusks. NOAA Tech Memo NMFSF/NEC 25, United States Department of Commerce, Woods Hole, MA

Jahromi SS (1977) Occurrence of rhabdovirus-like particles in the blue crab, Callinectes sapidus. J Gen Virol 36: 485-494

Johnson PT (1977) A viral disease of the blue crab, Callinectes sapidus: histopathology and differential diagnosis. J Invertebr Pathol 29:201-209

Johnson PT (1978) Viral diseases of the blue crab, Callinectes sapidus. Mar Fish Rev 40:13-15

Johnson PT (1980) Histology of the blue crab, Callinectes sapidus, a model for the decapoda. Praeger, New York, NY

Johnson PT (1983) Diseases caused by viruses, rickettsiae, bacteria, and fungi. In: Provenzano AJ (ed) The biology of crustacea: pathology, Vol 6. Academic Press, New York, NY, p 114-153

Johnson PT (1984) Viral diseases of marine invertebrates. In: Kinne O, Bulnheim HP (eds) Diseases of marine organisms. Helgoländer Meeresuntersuchungen, Vol 37. Biol Anstalt Helgoland, Hamburg, p 65-98

Johnson P (1986) Blue crab (Callinectes sapidus Rathbun) viruses and the diseases they cause. In: Perry HM, Malone RF (eds) Proceedings of the national symposium on the soft shelled blue crab fishery. MS-AL SeaGrant MASGP86-017, Ocean Springs, MS, p 13-19

Johnson PT, Bodammer JE (1975) A disease of the blue crab, Callinectes sapidus, of possible viral etiology. J Invertebr Pathol 26:141-143

Johnson PT, Lightner D (1988) Rod-shaped nuclear viruses of crustaceans: gut-infecting species. Dis Aquat Org 5: 123-141

Lacoste A, Malham SK, Gélébart F, Cueff A, Poulet SA (2002) Stress-induced immune changes in the oyster Crassostrea gigas. Dev Comp Immunol 26:1-9

Lakshmi GJ, Trigg CM, Perry HM (1984) The effect of ammonia accumulation on blue crab shedding success. Project No: R/RD-2 final report, Mississippi-Alabama Sea Grant Consortium, Ocean Springs, MS

Lane DJ (1991) 16S/23S rRNA sequencing. In: Stackebrandt E, Goodfellow M (eds) Nucleic acid techniques in bacterial systematics. John Wiley \& Sons, Chichester, p 115-175

Laughlin RA (1982) Feeding habits of the blue crab, Callinectes sapidus Rathbun, in the Apalachicola estuary, Florida. Bull Mar Sci 32:807-822

Le Moullac G, Haffner P (2000) Environmental factors affecting immune responses in Crustacea. Aquaculture 191: 121-131

Li C, Shields JD (2007) Primary culture of hemocytes from the Caribbean spiny lobster, Panulirus argus, and their susceptibility to Panulirus argus Virus 1 (PaV1). J Invertebr Pathol 94:48-55

Luna LG (1968) Manual of histological staining methods of the Armed Forces Institute of Pathology, 3rd edn. McGraw-Hill, New York, NY

Maan S, Rao S, Maan NS, Anthony SJ, Attoui H, Samuel AR, Mertens PPC (2007) Rapid cDNA synthesis and sequencing techniques for the genetic study of bluetongue and other dsRNA viruses. J Virol Methods 143:132-139
Maryland Department of Natural Resources (2008) DNR announces estimated 2007 blue crab harvest numbers. www.dnr.state.md.us/dnrnews/pressrelease2008/020408. html (accessed 30 Dec 2009)

Mayo MA, Haenni AL (2006) Report from the 36th and 37th meetings of the executive committee of the International Committee on Taxonomy of Viruses. Arch Virol 151: 1031-1037

Messick GA, Kennedy VS (1990) Putative bacterial and viral infections in blue crabs, Callinectes sapidus, held in a flow-through or a recirculating shedding system. J Shellfish Res 9:33-40

Millonig G (1976) Laboratory manual of biological electron microscopy. M. Saviolo, Vercelli

Montane MM, Lowery WA (2005) Estimating relative juvenile abundance of ecologically important finfish and invertebrates in the Virginia portion of Chesapeake Bay, project \#na03nmf4570378. Annual Report to NOAA Chesapeake Bay Office for Fiscal Year 2004, Virginia Institute of Marine Science, Gloucester Point, VA

> Montanie H, Bossy JP, Bonami JR (1993) Morphological and genomic characterization of two reoviruses ( $\mathrm{P}$ and $\mathrm{W} 2$ ) pathogenic for marine crustaceans; do they constitute a novel genus of the Reoviridae family? J Gen Virol 74: 1555-1561

Morris-Krsinich B, Hull R (1983) Replication of turnip rosette virus RNA in inoculated turnip protoplasts. J Gen Virol 64:2661-2668

> Moss SR, Nutall PA (1995) Comparison of the non-structural protein, NS1, of tick-borne and insect-borne orbiviruses. Virus Res 36:287-292

> Navarro SA, Tang FJK, Lightner DV (2009) An improved Taura syndrome virus (TSV) RT-PCR using newly designed primers. Aquaculture 293:290-292

Nejstgaard JC, Frischer ME, Raule CL, Gruebel R, Kohlberg KE, Verity PG (2003) Molecular detection of algal prey in copepod guts and fecal pellets. Limnol Oceanogr Methods $1: 29-38$

> Newman MW, Johnson CA (1975) A disease of blue crabs (Callinectes sapidus) caused by a parasitic dinoflagellate, Hematodinium sp. J Parasitol 61:554-557

Noga EJ, Sawyer TK, Rodon-Naveira M (1998) Disease processes and health assessment in blue crab fishery management. J Shellfish Res 17:567-577

Roy P, Noad R (2006) Bluetongue virus assembly and morphogenesis. Curr Topics Microb Immunol 309:87-116

Sambrook J, Fritsch EF, Maniatis T (1989) Molecular cloning: a laboratory manual, 2nd edn. Cold Spring Harbor Laboratory Press, New York, NY

Shields JD (2003) Research priorities for diseases of the blue crab Callinectes sapidus. Bull Mar Sci 72:505-517

Shields JD, Overstreet RM (2007) Diseases, parasites, and other symbionts. In: Kennedy VS, Cronin LE (eds) The blue crab: Callinectes sapidus. Maryland Sea Grant College Publication UM-SG-TS-2007-1, College Park, MD, p 223-339

Shields JD, Behringer DC (2004) A new pathogenic virus in the Caribbean spiny lobster Panulirus argus from Florida. Dis Aquat Org 59:109-118

Summons DT, Steaitss JH (1972) Replication of sindbis virus. II. Multiple forms of double-stranded RNA isolated from infected cells. J Mol Biol 71:615-631

Smith HM (1891) Notes on the crab fishery of Crisfield, MD. Bull US Fish Comm 9:103-112

Sprague V, Beckett RL (1966) A disease of blue crabs (Callinectes sapidus) in Maryland and Virginia. J Invertebr Pathol 8:287-289 
Towle DW, Rushton ME, Heidysch D, Magnani JJ and others (1997) Sodium/proton antiporter in the euryhaline crab Carcinus maenas: molecular cloning, expression and tissue distribution. J Exp Biol 200:1003-1014

Tsai JM, Shiau LJ, Lee HH, Chan PW, Lin CY (2002) Simultaneous detection of white spot syndrome virus (WSSV) and Taura syndrome virus (TSV) by multiplex reverse transcription-polymerase chain reaction (RT-PCR) in Pacific white shrimp Penaeus vannamei. Dis Aquat Org 50:9-12

Valverde RA, Nameth ST, Jordan RL (1990) Analysis of double-stranded RNA for plant virus diagnosis. Plant Dis 74:255-258

Weber F, Wagner V, Rasmussen SB, Hatmann R, Paludan SR (2006) Double-stranded RNA is produced by positivestrand RNA viruses and DNA viruses but not in detectable amounts by negative-strand RNA viruses. J Virol 80: 5059-5064

> Weidner E (1970) Ultrastructural study of microsporidian development. I. Nosema sp. Sprague 1965 in Callinectes

Editorial responsibility: Grant Stentiford, Weymouth, UK sapidus. Z Zellforsch Mikrosk Anat 105:33-54

Welsh PC, Sizemore RK (1985) Incidence of bacteremia in stressed and unstressed populations of the blue crab Callinectes sapidus. Appl Environ Microbiol 50:420-425

Weng SP, Guo ZX, Sun JJ, Chan SM, He JG (2007) A reovirus disease in cultured mud crab, Scylla serrata, in southern China. J Fish Dis 30:133-139

Williams AB (1974) The swimming crabs of the genus Callinectes (Decapoda: Portunidae). Fish Bull 72:685-798

Zhang S, Shi Z, Zhang J, Bonami JR (2004) Purification and characterization of a new reovirus from the Chinese mitten crab, Eriocheir sinensis. J Fish Dis 27:687-692

- Zmora O, Findiesen A, Stubblefield J, Frenkel V, Zohar Y (2005) Large-scale juvenile production of the blue crab Callinectes sapidus. Aquaculture 244:129-139

Zohar Y, Hines AH, Zmora O, Johnson EG and others (2008) The Chesapeake bay blue crab (Callinectes sapidus): a multidisciplinary approach to responsible stock enhancement. Rev Fish Sci 16:24-34

Submitted: March 31, 2010; Accepted: August 26, 2010

Proofs received from author(s): November 8, 2010 